\title{
OCCURRENCE OF FILAMENTOUS FUNGI IN SIMULIUM GOELDII CERQUEIRA \& NUNES DE MELLO (DIPTERA: SIMULIIDAE) LARVAE IN CENTRAL AMAZONIA, BRAZIL
}

\author{
Quézia Ribeiro Fonseca' ${ }^{1}$; Maria Inez de Moura Sarquis² ${ }^{2}$ Neusa Hamada ${ }^{1}$; Yamile Benaion Alencar ${ }^{1 *}$ \\ ${ }^{1}$ Coordenação de Pesquisas em Entomologia, Instituto Nacional de Pesquisas da Amazônia, Manaus, AM, Brasil; \\ ${ }^{2}$ Departamento de Micologia, Instituto Oswaldo Cruz, Manguinhos, RJ, Brasil.
}

Submitted: April 26, 2007; Returned to authors for corrections: February 26, 2008; Approved: April 25, 2008.

\section{SHORT COMMUNICATION}

\begin{abstract}
The family Simuliidae is the host of simbiontes fungi that inhabit the digestive tracts of arthropods. This paper reports the presence of fungi in Simulium goeldii Cerqueira \& Nunes de Mello larvae in Amazonia. We observed that the larvae are a good component of aquatic systems to isolate filamentous fungi.
\end{abstract}

Key-words: Black fly, Simulium, aquatic insects, Fungi

The family Simuliidae (Diptera: Nematocera) is known worldwide for its medical importance. Several species have been listed as hosts of Trichomycetes fungi that are obligate inhabitants of the digestive tracts of several Arthropoda; this class of fungi is included in the group of organisms with biotechnological potential, being of interest for pharmacological use and for use in the insecticide industry. Several species of Trichomycetes have been described in the Amazon region $(1,19,23)$. However, there is a lack of studies in this region on the relationship of these fungi to other microorganisms associated with aquatic insects.

Simulium goeldii Cerqueira \& Nunes de Mello has a wide distribution in the Amazon region. Its immatures inhabit small acidic streams in the forest $(6,12,13)$. Larvae are filter feeders and can be found on different substrates, occurring in higher density on the leaves of aquatic macrophytes, and on deciduous leaves and roots from trees that grow on the stream banks (11). Although the female of this species is not anthropophilic, studies of the population of this species can contribute to knowledge of the biology and ecology of black flies in Amazonia. The objective of the present study is to isolate and identify the fungi associated with S. goeldii larvae in Central Amazonia,
Brazil. This study is the first step towards selecting fungal lineages of biotechnological interest with a view to their use in the biological control of insect vectors of tropical diseases.

This study was conducted from April to October 2004 at different localities in the municipalities of Manaus, Presidente Figueiredo and Rio Preto da Eva (Amazonas) (Table 1).

Larvae of $S$. goeldii were collected using forceps, placed in containers and stored under refrigeration before being dissected in the laboratory. The larvae were dissected in distilled water with forceps and needles. Morphological characters used for species characterization were the same as those used in conventional studies of black-fly systematics $(5,12)$. Voucher specimens are deposited in the Invertebrate Collection of the Instituto Nacional de Pesquisas da Amazônia (INPA), Manaus, Amazonas, Brazil.

Larvae were separated and stored in test tubes in groups of ten specimens and sterilized by consecutive baths in sterile distilled water and $70 \%$ alcohol for 2 seconds each; Each Simuliidae species pool was composed of 10 insects that were macerated in $0.2 \mathrm{ml}$ of saline solution $(0.9 \%)$. The macerated samples were processed using the technique of Alves (2), 0.1 $\mathrm{ml}$ of the macerated sample was seeded onto Petri dishes

\footnotetext{
This study received financial support from the Fundação de Amparo a Pesquisa do Estado do Amazonas/FAPEAM (PIPT/827/03, DCR/954/03) and the Conselho Nacional de Desenvolvimento Científico e Tecnológico-CNPq.

*Corresponding Author. Mailing address: Coordenação de Pesquisas em Entomologia, Instituto Nacional de Pesquisas da Amazônia, Caixa Postal 478, 69011-970, Manaus, AM, Brazil. Fax: 55923643 3217. E-mail:yamile@inpa.gov.br
} 
Table 1. Simulium goeldii (Diptera: Simuliidae) collection sites in Amazonia.

\begin{tabular}{|c|c|c|c|c|}
\hline Site & Habitat & Date & Collector & Longitud/ Latitud \\
\hline 1 & $\begin{array}{l}\text { HW AM010 km 24, Reserva Florestal Adolpho } \\
\text { Ducke, Igarapé Barro Branco, Manaus municipality }\end{array}$ & $28 / 4 / 200402 / 5 / 2004$ & Fonseca, Q.R. & $02^{\circ} 34^{\prime} \mathrm{S} ; 60^{\circ} 07^{\prime} \mathrm{W}$ \\
\hline 2 & $\begin{array}{l}\text { HW AM010, Ramal Acará, Balneário da SEDUC, } \\
\text { Manaus municipality }\end{array}$ & $16 / 7 / 2004$ & Fonseca, Q.R. & $02^{\circ} 56^{\prime} \mathrm{S} ; 59^{\circ} 59^{\prime} \mathrm{W}$ \\
\hline 3 & $\begin{array}{l}\text { HW BR174 km 107, Igarapé da Santa Cláudia, } \\
\text { Presidente Figueiredo municipality }\end{array}$ & $18 / 5 / 2004$ & Fonseca, Q.R. & $02^{\circ} 02^{\prime} \mathrm{S} ; 60^{\circ} 00^{\prime} \mathrm{W}$ \\
\hline 4 & $\begin{array}{l}\text { HW AM010 km 02, Ramal Baixo Rio, Igarapé Família } \\
\text { Dó-re-mi, Rio Preto da Eva municipality }\end{array}$ & $28 / 9 / 2004$ & Alencar, Y.B. & $02^{\circ} 42^{\prime} \mathrm{S} ; 59^{\circ} 42^{\prime} \mathrm{W}$ \\
\hline
\end{tabular}

HW: highway; BR: Federal highway; AM: Amazonas state highway.

containing PDA (potato dextrose agar) culture media, to which $0.05 \mathrm{~g}$ per 1 of chloramphenicol was added. The plates were incubated at $28^{\circ} \mathrm{C}$ and examined every three days for 20 days. To preserve the genus of each isolate the colonies were transferred to test tubes $(16 \times 100 \mathrm{~mm})$ containing $5 \mathrm{ml}$ of PDA (2). These tubes were kept in a chamber under the same conditions of temperature $\left(28^{\circ} \mathrm{C}\right)$ and relative humidity $(80 \%)$.

To observe the macroscopic characteristics for identification of the various genera in each isolate, fragments of the colony grown in the test tubes were transplanted using a platinum loop to Petri dishes containing the media potato dextrose agar (PDA), Czapek-Dox-agar (CZ) and malt extract agar (MEA) (Difco), and were incubated at $28^{\circ} \mathrm{C}$.

The cultures were identified by microscopic characteristics (sexual and asexual) using the slide culture technique and specific literature $(3,8,14,20,21)$. Species were mounted in Amann lactophenol plus cotton blue and observed under a compound microscope.

Voucher cultures were preserved in hemolysis tubes $(15 \times$ $100 \mathrm{~mm}$ ) with PDA under a $1-\mathrm{cm}$ layer of mineral oil and incorporated in the fungus culture collection of the Instituto Nacional de Pesquisas da Amazônia (INPA) and Coleção de Culturas de Fungos do Departamento de Micologia, Instituto Oswaldo Cruz-FIOCRUZ/IOC.

A total of 50 larvae of $S$. goeldii were dissected, from which 36 fungal lineages were isolated. Of the isolated lineages, only $42 \%$ produced spores. The genera/species of fungi identified were: Aspergillus ochraceus Wilhelm, Penicillium bilaii Chalabuda, Penicillium chrysogenum Thom, Penicillium variabile Sopp, Paecilomyces aerugineus Samson, Beauveria bassiana (Bals.) Vuill., Metarhizium anisopliae (Metsch.) Sorokin, Trichoderma harzianum Rifai, Pestalotiopsis guepinii (Desm.) Stey, Scopulariopsis brevicaullis (Saccardo) Bainer, Acremonium sp. and Gliocadium sp. (Table 2).

The lineages that did not sporulate were inoculated in a poor culture medium, such as agar-water and agar-oats to induce
Table 2. Frequency of fungal isolates of $S$. goeldii larvae (Diptera: Simuliidae) collected at different localities in Amazonia

\begin{tabular}{lcc}
\hline \multicolumn{1}{c}{ Species } & $\begin{array}{c}\text { Isolated/ } \\
\text { Frequency }\end{array}$ & Site \\
\hline Acremonium sp. & $1(2.8)$ & 1 \\
Aspergillus ochraceus & $1(2.8)$ & 1 \\
Beauveria bassiana & $1(2.8)$ & 1 \\
Gliocadium sp. & $2(5.5)$ & 3 \\
Metarhizium anisopliae & $1(2.8)$ & 1 \\
Paecilomyces aerugineus & $2(5.5)$ & 1 \\
Penicillium bilaii & $1(2.8)$ & 2 \\
Penicillium chrysogenum & $1(2.8)$ & 4 \\
Penicillium variabile & $1(2.8)$ & 3 \\
Pestalotiopsis guepinii & $1(2.8)$ & 2 \\
Scopulariopsis brevicaullis & $1(2.8)$ & 1 \\
Trichoderma harzianum & $2(5.5)$ & 1 \\
Mycelia sterilia & $21(58.3)$ & $1,2,3,4$ \\
\hline
\end{tabular}

Notes: Collection number refers to sites listed in Table 1.

the production of spores; however, sporulation was not observed. The sterile lineages were preserved in sterilized distilled water and saved for later molecular identification.

The isolated fungi in this study are widely distributed in the environment and can be isolated from soil sample and plants (2). Some of the isolated lineages have associated entomopathogenic genera/species such as $M$. anisopliae, Acremonium, Paecilomyces, B. bassiana and T. harzianum $(2,16,17,18)$.

B. bassiana is frequently obtained from soil samples and insects (3), and lineages of this species are used to control populations of pest insects in the orders Coleoptera, Hemiptera, Lepidoptera, and some species of Diptera such as Musca domestica Linnaeus and Anastrepha ludens Loew $(3,16,17)$. 
M. anisopliae was the first species of fungus to be used in the microbial control of insects and occurs naturally in more than 300 species of different orders, including important pest insects. It is frequently used in the control of Deois flavopicta Stal and Zulia entreriana Berg (2).

Wicklow et al. (27) reported that Acremonium produce peptides with antimicrobial activity, having toxic properties and hability to form pores in membranes. This same study demonstrated that the antibiotic produced by Acremonium zeae Gams \& Sumner inhibits the growth of Aspegillus flavus Link and Fusarium verticillioides Sacc. (Nirenberg). Also, this antibiotic showed activity against Candida albicans Sullivan and several other Gram-negative bacteria.

The fungus $A$. ochraceus is pathogenic to humans and other animals, being known to produce ocratoxina $\mathrm{A}$, a toxic substance that contaminates food, especially grains such as corn and peanuts $(9,15)$.

In assays made with insects in the family Culicidae using lineages of the fungi Penicillium, Aspergillus and Trichoderma it was observed larval mortality of nearly $70 \%$ over a period that rarely reached 72 hours (18). Several papers about Trichoderma have reported its potential for producing antibiotic peptides and hydrolytic enzymes; however, there is no report of the use of these metabolites to control insects $(4,10,24,25)$.

During this study some genera/species of fungi known worldwide as important in the biological control of crop pests such as M. anisopliae and B. bassiana, were isolated from black-fly larvae. Also, from this insect fungi were isolated that are known to produce compounds of biotechnological interest, such as T. harzianum and Acremonium, but there are few studies of its potential for biological control of insect vectors of tropical diseases. Future studies on the lineages obtained need to be done to increase our knowledge of microorganisms with biotechnological potential in the Amazon region, thereby contributing to strengthening applied research in this region.

\section{RESUMO}

\section{Ocorrência de fungos filamentosos associados a larvas de Simulium goeldii Cerqueira $\&$ Nunes de Mello da Amazônia Central, Brasil}

A família Simuliidae é hospedeira de fungos simbiontes que habitam o trato digestivo de artrópodos. Este estudo reporta a presença de fungos em larvas de Simulium goeldii Cerqueira \& Nunes de Mello da Amazônia. Foi observado que as larvas são bons componentes do sistema aquático para isolar fungos filamentosos.

Palavras-chave: Borrachudo, Simulium, insetos aquáticos, fungos

\section{REFERENCES}

1. Alencar, Y.B.; Ríoz-Velasquez, C.M.; Lichtwardt, R.W.; Hamada, N. (2003). Trichomycetes (Zygomycota) in the digestive tract of Arthropods in Amazonas, Brasil. Mem. Inst. Oswaldo Cruz, 98 (6), 799-810.

2. Alves, S.B. (1998). Controle microbiano de insetos. Ed. FEALQ, Piracicaba.

3. Arx, J.A.V. (1981). The genera of fungi sporulating in pure culture. Ed. J. Cramer.

4. Berg, A.; Grigoriev, P.A.; Degenkolb, T.; Neuhof, T.; Hartl, A.; Schlegel, B. (2003). Isolation, structure elucidation and biological activities of trichofumins A, B, C and D, new 11 and 13 mer peptaibols from Trichoderma sp. HKI 0276W. J. Pept. Sci., 9 (11-12), 810-6.

5. Coscarón, S. (1990). Taxonomía y distribución del subgénero Simulium (Ectemnaspis) Enderlein (Simuliidae), Diptera, Insecta. Ilheringia, Sér. Zool., 70, 109-170.

6. Dellome Filho, J. (1983). Considerações sobre os fatores físicoquímicos dos criadores de Simulium goeldii Cerqueira \& Mello, 1967 (Diptera - Simuliidae). Rev. Bras. Ent., 27, 155-160.

7. Dirheimer, G.; Creppy, E.E. (1991). Mechanism of action of ochratoxin A. IARC Sci. Publ., (115), 171-86.

8. Ellis, M.B. (1971). Dematiaceous Hyphomycetes. Commonwealth Mycological Institute Kew, Surrey, UK.

9. Galtier, P. (1991). Pharmacokinetics of ochratoxin A in animals. IARC Sci. Publ., 187-200.

10. Goulard, C.; Hlimi, S.; Rebuffat, S.; Bodo, B. (1995). Trichorzins HA and MA, antibiotic peptides from Trichoderma harzianum. I. Fermentation, isolation and biological properties. J. Antibiot., 48 (11), 1248-53.

11. Hamada, N. (1993). Abundância de larvas de Simulium goeldii (Diptera: Simuliidae) e caracterização do seu habitat em uma floresta de terra firme, na Amazônia Central. Bol. Mus. Para. Emilio goeldii., 9 (2), 203-218.

12. Hamada, N.; Adler, P.H. (2001). Bionomia e chave para imaturos e adultos de Simulium (Diptera: Simuliidae) na Amazônia Central, Brasil. Acta Amazonica, 31 (1), 109-132.

13. Hamada, N.; McCreadie, J.W.; Adler, P.H. (2002). Species richness and spatial distribution of black flies (Diptera: Simuliidae) in streams of Central Amazonia, Brazil. Freshw. Biol., 47, 31-40.

14. Klich, M.A. (2002). Identification of common Aspergillus species. Centraalbureau voor Schimmelcultures, Utrecht, The Netherlands.

15. Kuiper-Goodman, T.; Scott, P.M. (1989). Risk assessment of the mycotoxin ochratoxin A. Biomed. Environ. Sci., 2, 179-248.

16. Lecuona, R.E.; Turica, M.; Tarocco, F.; Crespo, D.C. (2005). Microbial control of Musca domestica (Diptera: Muscidae) with selected strains of Beauveria bassiana. J. Med. Entomol., 42 (3), 332-6.

17. Liu, H.; Skinner, M.; Parker, B.L.; Brownbridge, M. (2002). Pathogenicity of Beauveria bassiana, Metarhizium anisopliae (Deuteromycotina: Hyphomycetes), and other entomopathogenic fungi against Lygus lineolaris (Hemiptera: Miridae). J. Econ. Entomol., 95 (4), 675-81.

18. Moraes, A.M.L; Borba, C.M.; Costa, G.L.; Rodrigues, K.; Sarquis, M.I.M. (1999). Fungos: Ferramenta na saúde pública. Biotecnolog. Cienc. Desenvolv., 7, 10-11.

19. Pereira, E.S.; Hamada, N.; Ferreira, R.L.M.; Lichtwardt, R.W. (2005). Trichomycete fungi (Zygomycota) associated with mosquito larvae (Diptera: Culicidae) in natural and artificial habitats in Manaus, AM, Brasil. Neotrop. Entomol., 34 (2), 325-329.

20. Pitt, J.I. (1985). A laboratory guide to common Penicillium species. CSIRO Division of food Research.

21. Rapper, K.B.; Fennel, D.I. (1965). The Genus Aspergillus. The Williams \& Wilkins Company, United States of America.

22. Rifai, M.A. (1969). A revision of the genus Trichoderma. Mycological papers, $\mathrm{n}^{\circ} 116$. 
23. Ríos-Velásquez, C.M.; Hamada, N. (2002). Trichomycete fungi (Zygomycota) associated with the digestive tract of Simulium goeldi Cerqueira \& Nunes de Mello and Simulium ulyssesi (Py-Daniel \& Coscarón) (Diptera: Simuliidae) larvae in Central Amazônia, Brasil. Mem. Inst. Oswaldo Cruz, 97 (3), 423-426.

24. Szekeres, A.; Leitgeb, B.; Kredics, L.; Antal, Z.; Hatvani, L.; Manczinger, L.; Vagvolgyi, C. (2005). Peptaibols and related peptaibiotics of Trichoderma. A review. Acta Microbiol. Immunol., $52(2), 137-68$.
25. Solfrizzo, M.; Altomare, C.; Visconti, A.; Bottalico, A.; Perrone, G. (1994). Detection of peptaibols and their hydrolysis products in cultures of Trichoderma species. Nat. Toxins, 2 (6), 360-5.

26. Sutton, B.C. (1980). The Coelomycetes fungi imperfecti with pycnidia acervuli and stromata. Commonwealth Mycological Institute Kew, Surrey, UK.

27. Wicklow, D.T.; Roth, S.; Deyrup, S.T.; Gloer, J.B. (2005). A Protective endophyte of maize: Acremonium zeae antibiotics inhibitory to Aspergillus flavus and Fusarium verticillioides. Mycol. Res., 109 (5), 610-8. 